\title{
Arthur Frederick Wright
}

$$
1913-1976
$$

Arthur Frederick Wright ( $1913-1976$ ), in addition to being a distinguished scholar, was one of the prime movers of the Association for Asian Studies; members of today should know something of what he contributed. He was both a classicist and an entrepreneur, a combination of qualities that contributed greatly to sinological scholarship and to the work of the AAS.

Coming from Portland, Oregon by way of Stanford (A.B. 1935), Arthur Wright had a Westerner's enthusiasm for growth and innovation. Yet he put in years of hard work at Oxford (B. Litt. I 937), Harvard (A.M. I 940, Ph.D. 1947), Kyoto (1 940-4 I, 1953-54) and Peking (I 94I-42, I 945-47), to acquire the command of languagesFrench, German, Chinese, Japanese-and of texts and bibliography necessary for classical sinology at the topmost level. In an age of galloping egalitarianism he was outspokenly elitist, seeking excellence, denouncing the banal and meretricious. Yet he was a warm friend, congenial and expansive, a natural host, a very competent golfer, a connoisseur and gourmet, and devoted to kindred spirits in many parts of the world. With all these personal qualities, he also developed a shrewd judgment of the competence of scholars and the practicalities of finance and publishing.

For the AAS, Arthur did everything one person could do. He was chairman of the program committee ( 1950 ), then editor of the journal* for four years in a formative era (I95 I-55), then a director (I955-58), vice president and president (1963-65). He guided the Committee on International Scholarly Liaison in I 962-65, and headed the finance committee for the 27 th International Congress of Orientalists in 1967 . At the same time, he negotiated the Ford Foundation grant of \$ I 20,000 for AAS projects I 966-7 I. The rather typical American activism of his early record, when he was also professor of history at Stanford, makes a fascinating counterpoint to his simultaneous growth as a scholar.

Arthur Wright's original field of research was the history of Buddhism; his first publications were studies of the early missionary-monk Fo-t 'u-teng, and of the attacks on Buddhism launched by Fu I in the early seventh century. From the outset, he was disenchanted with the philological and theological scholasticism of traditional Buddhist studies; his own work explored the relationships between Buddhism and politics in a broadly conceived frame of historical reference. He further pursued this line in a study of the formation of Sui ideology, which showed how the Sui emperors manipulated Buddhism for political purposes; he recently returned to this same theme in a study of 'T'ang T'ai-tsung's Buddhist policies. These early studies were summarized in

*Far Eastern Quarterly, which later became Journal of Asian Studies. 
I 958 in Buddbism in Chinese History, which places Buddhism in the grand sweep of China's medieval history in little more than a hundred pages full of original insights. This little book exemplified Arthur's great gifts as a historian: his gift for high-level synthesis, an ability to identify major problems in a mass of confusing detail, an uncanny feeling for the interplay of ideas and events, and the ability to present complex issues in a deceptively simple, lucid, and elegant prose style.

In his attempt to grasp China's medieval history as a whole, as in many of his basic interpretative insights, Arthur was much influenced by his friend Étienne Balazs of Paris who, like him, was in reaction against the traditional forms of sinological scholarship. It is difficult, after the lapse of a quarter of a century, to appreciate just what a change has come over the style of historical scholarship on the pre-modern period. Until the I950s, the usual approach had been the precise and heavily annotated translation of primary source materials, with their historical significance either summarized in a short preface, or simply left unstated. Very little of the scholarly literature was much more intelligible to the nonspecialist than if it had been left in the original language. Much of it was on themes of marginal importance. Balazs and Wright were leaders in a new generation that stressed the role of the sinological medievalist as a historian, writing for historians. They underlined the need first to identify significant problems, and then to present the results of research in a broad historical context, rather than remaining obsessed with scholarly minutiae-with "scholarly nit-picking," in Arthur's favorite words. The result has been a transformation, for there is now a growing body of mature historical writing on these periods comparable in approach and quality to what is done in Western history.

These changes were helped by Arthur in another role, as chairman of the AAS Committee on Chinese Thought during the decade 195 I-6I. During the I950s, his energies were increasingly involved in organizing its conferences which resulted in five symposium volumes that have become extremely influential. These conferences, unlike the unplanned traditional meetings of learned societies, brought together a picked group of participants who prepared substantial papers in advance on subjects related to a central theme. Bringing together both established scholars and young people of promise from a variety of countries, these meetings produced wide-ranging discussions at the highest professional level, in a relaxed and good-humored atmosphere of mutual endeavor which was largely generated by Arthur's warm personality. These conferences did a great deal to give our scattered field a sense of common purpose, and they changed Chinese studies in many ways. Small scholarly meetings of specialists have increasingly proved an effective strategy for the exploration of new fields. Current work and interest in Taoism, Neo-Confucianism, pre-modern urbanization, political legitimation, genre theory, the history of law-all were primed by conferences of this sort, most of them arranged through Arthur's direct encouragement.

In this work of directing the efforts of the growing field of pre-modern Chinese history, one of the most important factors was the ACLS Committee on Studies of Chinese Civilization. This committee, of which Arthur was chairman and chief inspiration for the decade $1964-73$, was, more than any other body, responsible for the rapidly improving standards of the field, funding most of the major conferences, and steadily widening the areas of specialist research in every field of the humanities. Arthur made it an international body, representative of European as well as American studies. Its achievement was largely due to Arthur's vision, open-mindedness, and lively involvement in new lines of research, plus his own efforts in raising the necessary funding. 
This deep involvement in academic politics at the highest level and in the organization of scholarship did not mean that Arthur ceased to be a creative scholar. For some years in the 1960 s he was engaged in a study of the T"ang capital city, Ch'ang-an, on which he gave a memorable series of lectures in London in I 962-63 and on which he later delivered his presidential address to the AAS in 1964 . This work later led him to give his support to the research conferences on the Chinese city, held in I 968 and I 969 , which laid the foundation for recent work on urbanization. He also spent much of the last decade on a major project on the history of the Sui. His lengthy chapter for volume III of the Cambridge History of China is in press; this was expanded into a book which was left almost ready for publication. Another of his ongoing interests was in Chinese historiography, and particularly in the ways by which one can assess the traditional historians' judgments of individuals and their place in history. In I970-7 I he held a year-long seminar on Chinese and Comparative Historiography at Yale, to which he invited a wide range of scholars from elsewhere. To any of the participants in these stimulating meetings, and indeed to anyone who had heard Arthur speak about historiography, it is a matter of deep regret that the book he projected as a summary of the work of this seminar never materialized.

Arthur Wright moved from Stanford to Yale as professor of history in 1959 . He proved to be a fine, careful, and demanding teacher who made his students aware of the extraordinary richness and subtlety of China's intellectual heritage. At the same time, he became involved in restructuring Yale's approach to area studies; within a few years, he had achieved complete transformation of the graduate training program. In $196 \mathrm{I}$ he negotiated a major Ford Foundation grant (renewed and increased in I 966) that enabled Yale to implement his idea for a "Concilium in International and Area Studies," a body that would be more informal than the conventional "School" of area studies, more flexible and comprehensive than Yale's regular departmental system. As executive secretary of this Concilium from I 962 to 1965 , he helped develop not only his own area, through the Council on East Asian Studies, but also the Councils on Russian and East European Studies, Latin American Studies, African Studies, and Western European Studies. He remained chairman of the Council on East Asian Studies after he stepped down as executive secretary of the Concilium. Together with Professor John W. Hall and others, he negotiated another Ford grant for a series of research seminars on broad topics within Asian Studies, including his own seminar on historiography; he raised money from private donors for the training of selected advanced graduate students in East Asian Studies; and he coordinated the planning that led to Yale's continuing receipt of HEW grants for a Language and Area Center. Meantime he gave a major introductory lecture course to undergraduates every year, conducted at least three different graduate seminars, and directed dissertations on a wide range of topics from the T'ang to the period of the MingCh'ing transition.

One part of Arthur's accomplishment during the thirty years following I 940 was his many-sided support of a major historian of modern China, Mary Clabaugh Wright (I 917-1970). Her considerable achievement was in some degree also his. Subsequently, he was fortunate to marry Marya Wankowicz Welch, whose sympathy of spirit and practical effectiveness were the greatest possible help to him. At the time of his unexpected death last August he was just completing two volumes, which will soon be published.

Arthur's untimely death is a profound loss to our profession. The rapid progress of our studies, which he did so much to foster, has led to a new situation of growing specialization and new forms of inward-looking scholasticism. It becomes more diffi- 
cult every year to grasp the picture as a whole; the field needs, more than ever, men with a gift for wide-ranging synthesis, with curiosity and interest in all the very varied forms that Chinese studies are now taking. With Arthur Wright's death we have lost the man perhaps best able to provide such a general perspective and sense of direction. But the complex and various state of our field is in itself a tribute to his vision, foresight, and entrepreneurial skills. Few men have left their mark, both directly and indirectly, on any field of scholarship in the humanities as clearly as he has done.

Harvard University

JOHN K. FAIRBANK

Yale University

JONATHAN SPENCE

Cambridge University

DENIS TWITCHETT 


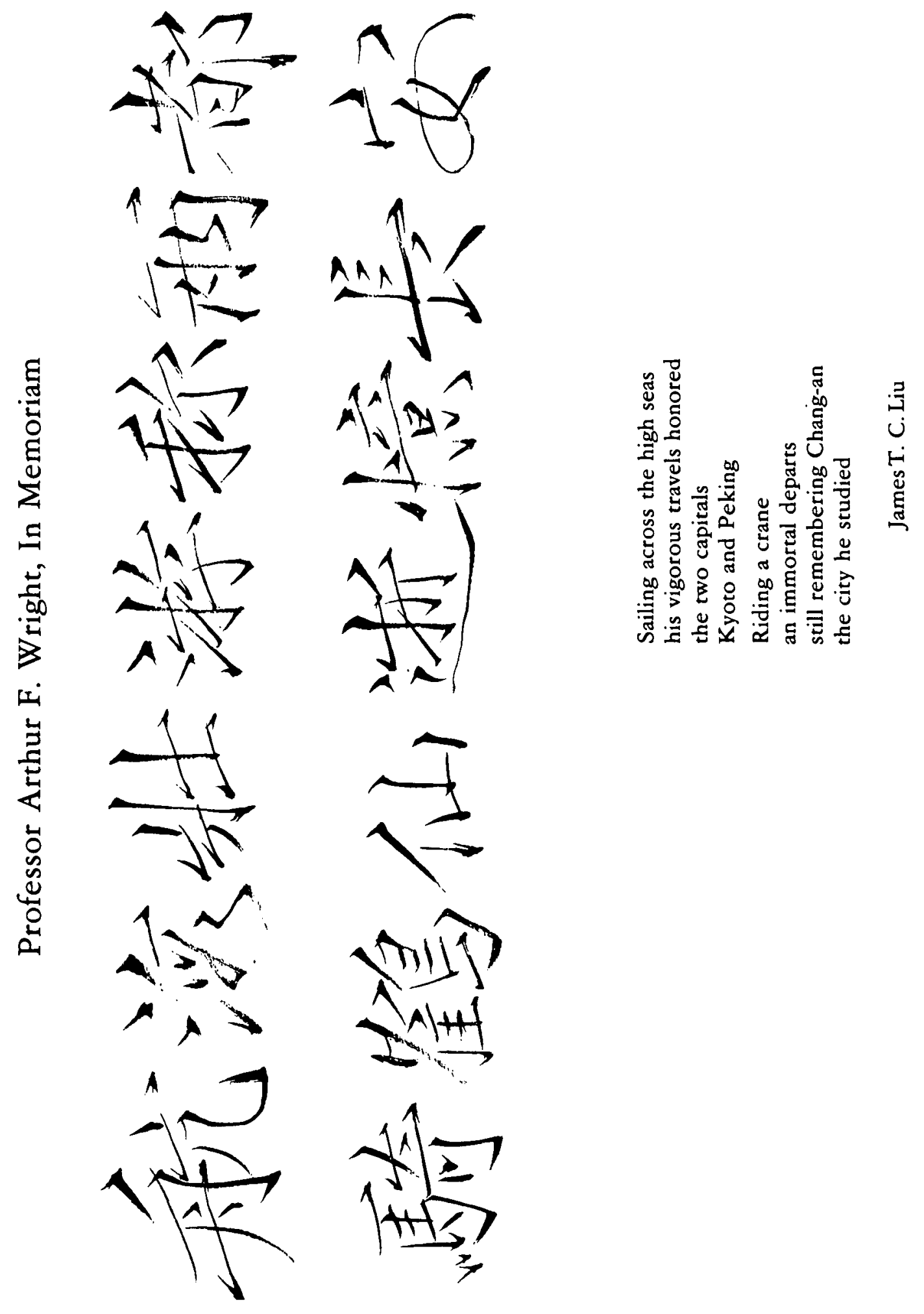

